\title{
The influence of organic production on food quality - research findings, gaps and future challenges
}

\author{
Aneta Załęcka, ${ }^{\mathrm{a}}{ }^{*}$ Susanne Bügel, ${ }^{\mathrm{b}}$ Flavio Paoletti, ${ }^{\mathrm{c}}$ Johannes Kahl, ${ }^{\mathrm{d}}$ \\ Adriana Bonanno, ${ }^{\mathrm{e}}$ Anne Dostalova ${ }^{\mathrm{f}}$ and Gerold Rahmanng
}

\begin{abstract}
Although several meta-analysis studies have been published comparing the quality of food derived from organic and non-organic origin, it is still not clear if food from organic production per se can guarantee product-related added value to consumers. This paper aims to summarize the status quo in order to identify research gaps and suggest future research challenges. Organic food is described according to a quality model already published. The influence of organic production on food quality is structured in primary production and processing. Furthermore, organic food authentication is discussed. Organic food seems to contain fewer pesticide residues and statistically more selected health-related compounds such as polyphenols in plant products and polyunsaturated fatty acids in milk and meat products, but the health relevance for consumers is not clear yet. Comparing food from organic origin with so called 'conventional' food seems not to be appropriate, because 'conventional' is not defined. In organic food quality research a system approach is needed from which systemic markers can be selected. Research on the impact of processing technologies on the quality according to organic principles seems of high relevance, since most of the food is processed.
\end{abstract}

○) 2014 Society of Chemical Industry

Keywords: food quality; organic; research challenges

\section{INTRODUCTION}

Since 2000 the organic food market has been growing all over the world, with yearly growth rates of about $10 \% .^{1,2}$ Consumers buy such food because they expect that it is healthier than food from non-organic production and because of environmental concerns. ${ }^{3-7}$ Until now, there seems to be a lack of evidence that food from organic production is significantly different from that from non-organic production in relation to product criteria such as nutrition or health impact. ${ }^{8-11}$ During the Second International Conference on Organic Food Quality and Health Research that took place in Warsaw, Poland in June 2013, scientists reported new findings on the impact of organic production on food quality. Based on this, they identified important research gaps and future research challenges in this field. The results are presented here, because they may be of interest for all scientists working on this topic.

\section{ORGANIC FOOD QUALITY}

Organic food production can be described as consumer-oriented. ${ }^{12,13}$ This was analyzed comparing concept and consumer awareness from organic to functional food. ${ }^{14}$ Kahl et al. ${ }^{15}$ identified gaps between consumer expectations and what can be guaranteed according to food quality through regulations and standards. To close this gap, a quality model for organic food was described recently, ${ }^{16}$ which puts together principles, criteria and measurable parameters making organic food quality operable. Most of the studies evaluating organic food quality are based on the measurement of selected food compounds (parameters) comparing food from organic versus non-organic origin. ${ }^{17}$

\section{INFLUENCE OF PRIMARY ORGANIC PRODUCTION ON PLANT AND ANIMAL FOOD QUALITY}

Nearly all studies evaluating organic food quality focus on the impact of primary production on the food attributes.

\footnotetext{
* Correspondence To: Aneta Załęcka, Department of Functional Food, Organic Food and Commodities, Warsaw University of Life Sciences, PL-02-776 Warszawa, Poland. azalecka@gmail.com

a Department of Functional Food, Organic Food and Commodities, Warsaw University of Life Sciences, PL-02-776 Warszawa, Poland

b Department of Human Nutrition, Faculty of Life Sciences, University of Copenhagen, DK-1958 Frederiksberg C, Denmark

c Consiglio per la Ricerca e la Sperimentazione in Agricoltura - Centro di Ricerca per gli Alimenti e la Nutrizione, Via Ardeatina 546, I-00178 Rome, Italy

d Department of Organic Food Quality and Food Culture, University of Kassel, D-37213 Witzenhausen, Germany

e Dipartimento Scienze Agrarie e Forestali, Settore di Produzioni Animali, Università degli Studi di Palermo, Palermo, Italy

$f$ Institute of Animal Science, Prague, Czech Republic
}

g Johann Heinrich von Thünen Institute of Organic Farming, Trenthorst, Germany 
Furthermore, most of the studies deal with parameters related to nutrition and health criteria. There is only a selection of measured single compounds and, in addition, this selection changes during time and between the studies. Comparing food from organic and non-organic production, several meta-analysis studies were published, but lack of data still exists, because only a few proper single studies have been published yet. Brandt et al. ${ }^{17}$ compared several meta-analyses carried out on the influence of production on plant foods. The outcome depends strongly on how the analysis is performed. Summarizing these different studies, it seems that plant products grown under an organic regime contain fewer pesticide residues and more of a few single compounds that have a potential health effect compared with food from non-organic production. The differences are of statistical significance, but it is not clear to what degree the enhanced content can be expected to affect human health. Another problem is that the putative health effect of each selected single compound is controversially discussed in scientific debates. According to the production, it seems to be clear that statistically fewer pesticide residues occur in organic than in non-organic food, because those chemicals are banned by regulations. To what degree fertilization influences the levels of food constituents is not clear yet. Although the kind and amount of $\mathrm{N}$ fertilization are regulated in organic food production, several other factors not regulated may also contribute. ${ }^{11}$ For some antioxidants it seems that the crop variety is one of the major factors influencing levels of these substances in the food. ${ }^{18}$

Palupi et al..$^{19}$ published the first meta-analysis on dairy products, indicating a higher content of polyunsaturated fatty acids in organic products than in non-organic samples. Besides the beneficial conjugated linolenic and $\alpha$-linolenic acids, also antioxidant compounds such as $\alpha$-tocopherol and carotenoids were observed to be higher in milk produced by cows under organic management than in non-organic milk..$^{20,21}$ In addition, sheep and goat dairy products from organic farming systems in Mediterranean environments showed a healthier fatty acid profile than products from conventional farms..$^{22,23}$ However, these findings are connected to the factor 'feeding regime', mainly in relation to the incidence of pasture forage in the diet of animals, which is regulated in organic animal husbandry. The difference is a probability, not a guarantee, as Kahl et al. ${ }^{15}$ discussed already. Non-organic rearing systems are not defined as a group of their own; that is, everything is not certified and therefore milk quality can differ to a certain degree, depending on whether cows grazed fresh forage at pasture or were housed indoors and fed hay and silage. Indeed, Butler et al. ${ }^{20}$ found no difference in health-promoting compounds in milk from cows grazing pasture between low-input organic and low-input non-organic systems.

It seems that appropriate grazing management, linked to the adoption of sustainable stocking rates and rotational pastures, regulating herbage allowance and intake by animals, could have a considerable effect on nutritional and health properties of dairy products. ${ }^{24,25}$ Moreover, the use as dietary supplements of alternative feeding sources to maize and soybean, such as locally grown cereal and legume grains that are free from genetically modified organisms (GMOs) and mycotoxins, seems to provide less expensive and safer organic animal products, with healthier fatty acid profile. ${ }^{26}$ Because not many studies exist, further investigations are needed on this topic.

\section{INFLUENCE OF ORGANIC PROCESSING ON FOOD QUALITY}

Although nearly $80 \%$ of food derived from organic production is processed, there are not many studies available investigating the effect of processing on food quality. ${ }^{27,28}$ Schmid and Beck ${ }^{29}$ gave the first overview on organic food processing, bringing concepts, methods and expectations from consumers and processors together. Very recently, Beck et al. ${ }^{30}$ identified research gaps and future research challenges in organic food processing. Food processing can be defined as the practices to transform raw plant and animal materials into intermediate foodstuffs or edible products for consumers through organized combinations of different unit operations such as washing, grinding, mixing, cooling, heating, freezing, etc.

Food processing has different aims, including ensuring microbiological and chemical safety of foods, adequate nutrient content and bioavailability to consumers, adequate acceptability to consumers with regard to sensory properties and ease of preparation, to increase the shelf life of food, food availability, variability of food supply, etc.

Processing causes changes in food and food properties: some changes are beneficial and necessary to achieve the objectives of the process; others are harmful and should be avoided as much as possible. Scientific research in food science and technology involves several disciplines (biology, chemistry, engineering, nutrition, sensory science, etc.). Progress in these disciplines has allowed us to find solutions to reduce, limit or control the harmful changes caused by food processing and to improve and enhance its efficacy and efficiency.

Considering the share of total organic sales, processed organic foods have a main role in the organic food market. ${ }^{31}$ Nevertheless, the current European organic regulation ${ }^{32}$ provides only generic indications about processing, permitting the use of the additives and processing aids included in a positive list, clearly prohibiting only the use of GMOs and irradiation, and recommending that the process should be performed with care and preferably with the use of biological, mechanical and physical methods, with exclusion of chemical methods.

In contrast to the generic indications of the European regulation, some private organic associations are more restrictive and prohibit the use of some technologies such as sterilization that are considered as not careful because they are too intense with regard to the product and its quality. However, the relation between food process and quality is a complex subject and generalization should be avoided. For example, heat treatment in addition to intense homogenization is responsible for higher lycopene availability in tomato paste than in fresh unprocessed tomato. The homogenization and heat treatment cause a breakdown of the tissue matrix, which weakens the bonding forces between lycopene and tissue matrix, thus making lycopene more accessible. ${ }^{33,34}$ Moreover, lycopene in fresh tomato fruits occurs essentially in all-trans configurations. During processing, these configurations are in part converted into cis isomers that are more easily absorbed by the human intestine. ${ }^{35,36}$

Canning is generally considered in a negative way because it can cause a significant destruction of heat-sensitive compounds such as ascorbic acid. However, canned products can be stored at room temperature for several months. Frozen food can be stored for a comparable length of time, even though the maintaining of $-18^{\circ} \mathrm{C}$ temperature involves high energy consumption. The impact of the freezing process on the ascorbic acid content of fruits and vegetables is significantly lower than that of canning and mostly 
due to the blanching treatment. ${ }^{37,38}$ However, if the ascorbic acid content is compared after 6 months of storage, the difference between frozen and canned green beans is less. Moreover, differently from canned ones, frozen vegetables need to be cooked before consumption, and cooking can cause additional ascorbic acid losses that, paradoxically, can bring the concentration in peas or spinach to be lower than that of the canned counterpart at consumption. ${ }^{38}$

However, if sensory quality of canned and frozen vegetables is compared, the latter should be preferred by consumers because they more closely resemble fresh counterparts in terms of taste, flavour and colour. In fact, freshness is one of the main factors influencing the food choice of European consumers. ${ }^{39,40}$ The number of products with fresh-like characteristics that consumers can find on the market has constantly increased in the last few decades. The currently adopted technological approach to food preservation is mainly based on slowing down microorganism growth and spoilage reactions rather than to guarantee the safety and shelf life of products through the destruction and inactivation of microorganisms and enzymes by intense heat treatments (canning, for example). On the one hand, this approach allows one to avoid the negative effect of severe heat treatments on the nutritional and sensory quality of the products; on the other hand, it implies the use of high-quality raw materials, overall from the microbiological point of view. This approach consists in placing a sequence of hurdles to microorganism growth and enzyme activity, thus allowing one to extend the shelf life of products while retaining the nutritional and sensory characteristics of the raw, unprocessed materials (e.g. fresh-cut salads). ${ }^{41}$ These products, commonly defined as 'minimally processed foods', need to be stored under refrigeration, and the control of the low temperature along the chain (cold chain) has to be guaranteed. Some food technologists include in this category of food products also those that have been exposed to controlled amounts of heat to deactivate pathogens, such as fresh milk or fresh pasta that has been heat pasteurized. According to the organic regulation (Art. 6, EC Regulation No 834/2007), the production of processed organic foods is based on a limited use of additives and processing with care, preferably with the use of biological, physical and mechanical methods. Minimal processing is in line with these principles.

In the last 20 years the innovation in food technology has been focused on (a) improving the efficiency and efficacy of heat treatments, with ohmic heating, ${ }^{42}$ radio frequency heating ${ }^{43}$ and infrared heating ${ }^{44}$ being examples of this, and (b) identifying alternative methods to heat treatments, with high pressure, ${ }^{45,46}$ cold plasma, ${ }^{47}$ pulsed electric fields ${ }^{48}$ and pulsed light ${ }^{49}$ representing the alternative techniques mainly studied. These techniques allow very rapid treatments and a reduction of unwanted thermal effects on food colour, flavour and nutrients. Therefore they seem promising for use in food stabilization while preserving nutritional and sensory quality characteristics. Although few data are still available on the environmental impact of these techniques, there are studies that indicate potential energy savings for some of them in comparison with traditional heat treatments. ${ }^{48}$ Notwithstanding this, the number of commercial applications of these techniques is still limited owing, in general, to high equipment costs, limited throughput, lack of effect on microbial spores, incomplete deactivation/inactivition of some enzymes or activation of latent forms of some enzymes, need of labour and lack of knowledge.

Among the emerging technologies, nanotechnology seems to be able to lead to a number of innovations that are expected to make a major impact on the agro-food sector. However, knowledge about this technology is still very scarce, particularly with respect to the implications for consumer safety. So far, few studies have been carried out on the potential consumer safety implications from the application of nanomaterials in the agro-food sector. For example, the potential effects of nanoparticles through the gastrointestinal route are largely unknown. In terms of environmental behaviour, the distribution and fate of nanoparticles are currently not fully understood, and it is difficult to assess whether nanoparticles in the environment will accumulate/concentrate in the food chain..$^{50}$ Biodegradable polymer-nanomaterial composites represent an application of nanotechnology that could be of interest for the sector of organic food processing. ${ }^{51}$ However, potential migration of nanoparticles into food and drink from the packaging could represent a risk for consumer safety, though few migration data are currently available..$^{50}$

\section{ORGANIC FOOD AUTHENTICATION}

One of the major issues in the organic food system is the integrity of the food chain. ${ }^{52}$ Although certification systems guarantee this 'added value', traceability through product measurements may help to detect fraud. Here the focus is not on the quality of the products, as described by Kahl et al., ${ }^{16}$ but on authentication regarding the process. Very recently, Capuano et al..$^{53}$ gave an overview of markers applied in analytical authentication of organic food. Also here, the studies mainly focusing on primary production have not taken into account that even organic food is mostly complex and processed. Furthermore, methods difficult to authenticate, such as stable isotopes or non-targeted techniques, are not or not easily related to food quality criteria such as nutrition and therefore cannot show if the plus expected is present in the food or not. Although most of the methods have shown their potential for application in principle, tests on large sample sets and under more practical conditions still have to be performed.

\section{IDENTIFIED RESEARCH GAPS}

We have clustered the identified research gaps according to two main areas: definitions and research methodology.

In Europe, organic production is defined through several EU regulations in accordance with national and/or private standards. ${ }^{32,54-56}$ Canada, Japan and the USA also have national regulations on organic food production. ${ }^{57-59}$ Furthermore, organic food production is described in Codex Alimentarius ${ }^{60}$ as a kind of worldwide agreed definition. Nearly all studies dealing with organic food quality determination compare food produced according to these regulations and standards with food produced in other ways. The term describing the non-organic origin is 'conventional'. 'Conventional' is everything that is not 'organic' but covers a whole range of different agricultural practices and processing technologies. Using this term in comparison with organic may indicate that 'conventional' is also a clearly defined system, which obviously it is not. The next problem is that organic regulations such as EU-834/200732 and EU-889/200861 give the possibility for a wide range of different agricultural practices and processing methods, because not all important factors are regulated or levels are not narrow enough to guarantee a certain range of product quality. Although organic specialists argue that the intention of organic farming and food production is focused on process-related aspects rather than product quality, consumers expect an added value also in the food itself. 
Within the research methodology area we clustered the research gaps into two groups: one reflects research problems occurring through the selection of the study design; the second reflects the problem of how to select the right markers for evaluation of the results.

Within the question of the study design, one of the main questions is whether the comparison between 'organic' and 'non-organic' is still the appropriate study design for evaluating the quality of organic food. What do we compare? It seems to be that samples from regulated production (organic), which still show a great variation, are compared with samples from not further defined production. Do we harvest plant samples from these different origins at the same time of harvest even though they may undergo different processes of maturation? This is also true for meat quality in terms of slaughter time, etc. The next problem is a statistical one: at what number of samples will we achieve a representative result? Furthermore, to what level, worldwide, European or regional, and for which products is this result representative? At least, what do we compare: single factors of influence such as fertilization or complete farming systems?

According to the quality model given by Kahl et al., ${ }^{16}$ it is not clear which indicators should be selected for studies evaluating organic food quality. Moreover, it seems that some parameters are applied because methods to measure them are available, without reflecting their contribution to organic food quality. Quality determination mainly follows single-parameter selection and not a system approach as would fit to the organic food system. Beck et al. $^{30}$ identified research gaps according to organic food quality in that they analysed the different levels for evaluation. Here some organic-specific indicators are not based on measurable parameters, for which methods have to be developed.

\section{FUTURE RESEARCH CHALLENGES}

We have clustered our different and mostly detailed research challenges into main topics. We do not give priority to them, as we think this is up to those dealing with the different areas.

In organic food quality research a system approach is needed in order to evaluate and improve the organic system from field to fork and according to the multidimensional quality model.

Food as a system has to be identified, described and quantified in order to relate the measured quality parameters or indicators to related criteria such as human health, well-being and environmental impact, including animal welfare.

Strategies for improving the quality of organic food should be developed, including adopted study design, methodology and markers. Instead of comparing two more or less undefined systems, an analysis of the critical steps within the organic production chain regarding their impact on food quality and consequently their improvement seems to be appropriate. Markers should be selected that describe the food as a system and in relation to the multiple quality dimensions, rather than reducing it to a few single constituents.

Furthermore, the analysis of best practices in primary production and processing may offer an efficient tool for improvement of organic food quality.

Because most organic food is processed, the evaluation of processing technologies seems of high relevance. Here existing technologies should be evaluated and improved as well as new ones developed that meet the requirements of organic food processing.
Food from related systems such as traditional and regional as well as fair trade, etc. should be included in the scope, because there seems to be several overlaps between organic and these different ways of food production. Research on the understanding of attitudes, behaviour and perception of consumers regarding organic food is necessary as an important basis for food quality research studies.

\section{ACKNOWLEDGEMENTS}

The authors thank all participants of the session 'Quality of food from organic and related systems' at the Second International Conference on Organic Food Quality and Health Research in Warsaw, 6 June 2013 for fruitful comments on this manuscript.

\section{REFERENCES}

1 Sahota A, Global organic food \& drink market. [Online]. Available: http://www.fibl.org/fileadmin/documents/en/news/2011/sahota2011-biofach-market.pdf [29 August 2013].

2 Organics and functional foods. A global Nielsen consumer report. [Online]. Available: http://pt.nielsen.com/documents/tr_0710_ OrganicsFood.pdf [29 August 2013].

3 Kriwy $P$ and Mecking R-A, Health and environmental consciousness, costs of behaviour and the purchase of organic food. Int J Consum Stud 36:30-37 (2012).

4 Pino G, Peluso AM and Guido G, Determinants of regular and occasional consumers' intentions to buy organic food. J Consum Aff 46:157-169 (2012).

5 Zagata L, Consumers' beliefs and behavioural intentions towards organic food. Evidence from the Czech Republic. Appetite 59:81-89 (2012).

6 Hjelmar U, Consumers' purchase of organic food products: a matter of convenience and reflexive practices. Appetite 56:336-344 (2011).

7 Hughner RS, McDonagh P, Prothero A, Shultz II CJ and Stanton J, Who are organic consumers? A compilation and review of why people purchase organic food. J Consum Behav 6:94-110 (2007).

8 Smith-Spangler C, Brandeau ML, Hunter GE, Bavinger JC, Pearson M, Eschbach PJ, et al., Are organic foods safer or healthier than conventional alternatives? A systematic review. Ann Intern Med 157:348-366 (2012).

9 Brandt K, Leifert C, Sanderson R and Seal CJ, Agroecosystem management and nutritional quality of plant foods: the case of organic fruits and vegetables. Crit Rev Plant Sci 30:177-197 (2011).

10 Hunter D, Foster M, McArthur JO, Ojha R, Petocz P and Samman S, Evaluation of the micronutrient composition of plant foods produced by organic and conventional methods. Crit Rev Food Sci Nutr 51:571-582 (2011).

11 Dangour AD, Dodhia SK, Hayter A, Allen E, Lock K and Uauy R, Nutritional quality of organic foods: a systematic review. Am J Clin Nutr 90:680-685 (2009).

12 Levidow L, Birch K and Papaioannou T, Divergent paradigms of European agro-food innovation. The Knowledge-Based Bio-Economy (KBBE) as an R\&D agenda. Sci Technol Hum Val 38:94-125 (2013).

13 Torjusen $\mathrm{H}$, Sangstad L, O'Doherty-Jensen $\mathrm{K}$ and Kjaernes U, European consumers' conceptions of organic food: a review of available research. Project Report 4-2004, National Institute for Consumer Research, Oslo (2004).

14 Kahl J, Załęcka A, Ploeger A, Bügel S and Huber M, Functional food and organic food are competing rather than supporting concepts in Europe. Agriculture 2:316-324 (2012).

15 Kahl J, van den Burgt G-J, Kusche D, Bügel S, Busscher N, Hallmann E, et al., Organic food claims in Europe. Food Technol 3:38-46 (2010).

16 Kahl J, Baars T, Bügel S, Busscher N, Huber M, Kusche D, et al., Organic food quality: a framework for concept, definition and evaluation from the European perspective. J Sci Food Agric 92:2760-2765 (2012).

17 Brandt K, Srednicka-Tober D, Baranski M, Sanderson R, Leifert C and Seal CJ, Methods for comparing data across differently designed agronomic studies: examples of different meta-analysis methods used to compare relative composition of plant foods grown using organic or conventional production methods, and a protocol for a systematic review. J Agric Food Chem 61:7173-7180 (2013). 
18 Roose $\mathrm{M}$, Kahl J and Ploeger A, Influence of the farming system on the xanthophyll content of soft and hard wheat. J Agric Food Chem 57:182-188 (2009).

19 Palupi E, Jayanegara A, Ploeger A and Kahl J, Comparison of nutritional quality between conventional and organic dairy products: a meta-analysis. J Sci Food Agric 92:2774-2781 (2012).

20 Butler G, Nielsen JH, Slots T, Seal C, Eyre MD, Sanderson R, et al., Fatty acid and fat-soluble antioxidant concentrations in milk from highand low-input conventional and organic systems: seasonal variation. J Sci Food Agric 88:1431-1441 (2008).

21 Butler G, Stergiadis S, Seal C, Eyre M and Leifert C, Fat composition of organic and conventional retail milk in northeast England. J Dairy Sci 94:24-36 (2011).

22 Tsiplakou E, Kotrotsios V, Hadjigeorgiou I and Zervas G, Differences in sheep and goats milk fatty acid profile between conventional and organic farming systems. J Dairy Res 77:343-349 (2010).

23 Tudisco R, Cutrignelli MI, Calabro S, Piccolo G, Bovera F, Guglielmelli A et al., Influence of organic systems on milk fatty acid profile and CLA in goats. Small Ruminant Res 88:151-155 (2010).

24 Dewhurst RJ, Shingfield KJ, Lee MR and Scollan ND, Increasing the concentrations of beneficial polyunsaturated fatty acids in milk produced by dairy cows in high-forage systems. Anim Feed Sci Technol 131:168-206 (2006).

25 Morand-Fehr P, Fedele V, Decandia M and Le Frileux Y, Influence of farming and feeding systems on composition and quality of goat and sheep milk. Small Ruminant Res 68:20-34 (2007).

26 Bonanno A, Tornambè G, Di Grigoli A, Genna V, Bellina V, Di Miceli G, et al., Effect of legume grains as a source of dietary protein on the quality of organic lamb meat. J Sci Food Agric 92:2870-2875 (2012).

27 Seidel K, Kahl J, Paoletti F, Birlouez I, Busscher N, Kretzschmar U, et al., Quality assessment of baby food made of different pre-processed organic raw materials under industrial processing conditions. J Food Sci Technol (2013). DOI: 10.1007/s13197-013-1109-5.

28 Särkkä-Tirkkonen $M$ and Leskinen $M$, Concept paper on processing methods and their labelling, in Organic Food Processing - Principles, Concepts and Recommendations for the Future. Results of a European Research Project on the Quality of Low Input Foods. FiBL-Report, ed. by Beck A, Kretzschmar U and Schmid O. Research Institute of Organic Agriculture (FiBL), Frick (Switzerland), pp. 40-43 (2006).

29 Schmid $O$ and Beck A, Development of organic agriculture and food processing, in Organic Food Processing - Principles, Concepts and Recommendations for the Future. Results of a European Research Project on the Quality of Low Input Foods. FiBL-Report, ed. by Beck A, Kretzschmar U and Schmid O. Research Institute of Organic Agriculture (FiBL), Frick (Switzerland), pp. 17-22 (2006).

30 Beck A, Kahl J and Liebl B, Analysis of the current state of knowledge of the processing and quality of organic food, and of consumer protection. BÖLN-Report 2012. [Online]. Available: https:// www.fibl.org/fileadmin/documents/shop/1584-anlysis-quva.pdf [25 July 2013].

31 An analysis of the EU organic sector. [Online]. Available: http://ec. europa.eu/agriculture/markets-and-prices/more-reports/pdf/ organic_2010_en.pdf [29 August 2013].

32 Council Regulation (EC) No 834/2007 of 28 June 2007 on organic production and labelling of organic products and repealing Regulation (EEC) No 2092/91.

33 Van het Hof KH, de Boer BCJ, Tijburg LBM, Lucius BRHM, Zijp I, West $\mathrm{CE}$, et al., Carotenoid bioavailability in humans from tomatoes processed in different ways determined from the carotenoid response in the triglyceride-rich lipoprotein fraction of plasma after a single consumption and in plasma after four days of consumption. $J$ Nutr 130:1189-1196 (2000).

34 Takeoka GR, Dao L, Flessa S, Gillespie DM, Jewell WT, Huebner B, et al., Processing effects on lycopene content and antioxidant activity of tomatoes. J Agric Food Chem 49:3713-3717 (2001).

35 Shi J and Le Maguer M, Lycopene in tomatoes: chemical and physical properties affected by food processing. Crit Rev Biotechnol 20:293-334 (2000).

36 Boileau TWM, Boileau AC and Erdman Jr JW, Bioavailability of all-trans and cis-isomers of lycopene. Exp Biol Med 227:914-919 (2002).
37 Favell DJ, A comparison of the vitamin C content of fresh and frozen vegetables. Food Chem 62:59-64 (1998).

38 Rickman JC, Barrett DM and Bruhn CM, Nutritional comparison of fresh, frozen and canned fruits and vegetables. Part 1. Vitamins $C$ and $B$ and phenolic compounds. J Sci Food Agric 87:930-944 (2007).

39 Ragaert P, Verbeke W, Devlieghere F and Debevere J, Consumer perception and choice of minimally processed vegetables and packaged fruits. Food Qual Prefer 15:259-270 (2004).

40 Péneau S, Hoehn E, Roth HR, Escher F and Nuessli J, Importance and consumer perception of freshness of apples. Food Qual Prefer 17:9-19 (2006).

41 Gould GW, Preservation: past, present and future. Br Med Bull 56:84-96 (2000).

42 Knirsch MC, dos Santos CA, Vicente AA and Penna TC, Ohmic heating: a review. Trends Food Sci Technol 21:436-441 (2010).

43 Marra F, Zhang L and Lyng JG, Radio frequency treatment of foods: review of recent advances. J Food Eng 91:497-508 (2009).

44 Krishnamurthy K, Khurana HK, Jun S, Irudayaraj J and Demirci A, Infrared heating in food processing: an overview. Compr Rev Food Sci Food Saf 7:2-13 (2008).

45 Rastogi NK, Raghavarao KSMS, Balasubramaniam VM, Niranjan K and Knorr D, Opportunities and challenges in high pressure processing of foods. Crit Rev Food Sci Nutr 47:69-112 (2007).

46 Norton T and Sun DW, Recent advances in the use of high pressure as an effective processing technique in the food industry. Food Bioprocess Technol 1:2-34 (2008).

47 Banu MS, Sasikala P, Dhanapal A, Kavitha V, Yazhini G and Rajamani $\mathrm{L}$, Cold plasma as a novel food processing technology. Int J Emerg Trends Eng Dev 4:803-818 (2012).

48 Toepfl S, Mathys A, Heinz V and Knorr D, Potential of high hydrostatic pressure and pulsed electric fields for energy efficient and environmentally friendly food processing. Food Rev Int 22:405-423 (2006).

49 Vicente M, Lopez G, Ragaert P, Debevere J and Devlieghere F, Pulsed light for food decontamination: a review. Trends Food Sci Technol 18:464-473 (2007).

50 Chaudhry Q, Scotter M, Blackburn J, Ross B, Boxall A, Castle L, et al., Applications and implications of nanotechnologies for the food sector. Food Addit Contam 25:241 - 258 (2008).

51 De Melo C, Garcia PS, Grossmann MW, Yamashita F, Dall'Antonia LH and Mali S, Properties of extruded xanthan-starch-clay nanocomposite films. Braz Arch Biol Technol 54:1223-1333 (2011).

52 Morgan K and Murdoch J, Organic vs. conventional agriculture: knowledge, power and innovation in the food chain. Geoforum 31:159-173 (2000).

53 Capuano E, Boerrigter-Eenling R, van der Veer G and van Ruth S, Analytical authentication of organic products: an overview of markers. J Sci Food Agric 93:12-28 (2013).

54 Demeter. [Online]. Available: http://www.demeter.net/certification/ standards [25 July 2013].

55 Bioland. [Online]. Available: http://www.bioland.de/bioland/ richtlinien.html [25 July 2013].

56 IFOAM. [Online]. Available: http://www.ifoam.org/en/ifoam-standard [25 July 2013].

57 Organic production systems: general principles and management standards. [Online]. Available: http://certifiedorganic.bc.ca/ standards/docs/032_0310_2006-e_Amend_\%202008,\%202009, $\% 202011$ Repr_Aug_2011_incorpCorr_1.pdf [25 July 2013].

58 MAFF. [Online]. Available: http://www.maff.go.jp/e/jas/specific/ criteria_o.html [25 July 2013].

59 USDA. [Öline]. Available: http://www.usda.gov/wps/portal/usda/ usdahome?navid=ORGANIC_CERTIFICATION [25 July 2013].

60 Codex Alimentarius, Guidelines for the Production, Processing, Labelling and Marketing of Organically Produced Foods (GL 32-1999) (adopted 1999, revisions 2001, 2003, 2004 and 2007, amendments 2008, 2009 and 2010). Codex Alimentarius, Rome (2010).

61 Commission Regulation (EC) No 889/2008 of 5 September 2008 laying down detailed rules for the implementation of Council Regulation (EC) No 834/2007 of 28 June 2007 on organic production and labelling of organic products with regard to organic production, labelling of organic products and control. 